\title{
Studies on Heterosis in Ridge Gourd [Luffa accutangula (L) Roxb]
}

\author{
D. Nandhini*, M. Ananthan, V. Krishnamoorthy and G. Anand \\ Department of Horticulture, AC\&RI, TNAU, Madurai-625 104, India \\ Department of Vegetable Crops, HC\&RI, TNAU, Coimbatore-641 003, India \\ *Corresponding author
}

\begin{abstract}
A B S T R A C T
\section{Keywords}

Ridge gourd, Fruit yield, Heterosis, Yield

components

Article Info

Accepted:

22 April 2018

Available Online:

10 May 2018

A study was carried out at Department of Horticulture, Agricultural College and Research Institute, Madurai during 2015-2016. Sixteen $\mathrm{F}_{1}$ crosses of ridge gourd obtained through a Line $\times$ Tester crosses involving eight parents were evaluated to study heterosis for growth, and yield parameters. Maximum standard heterosis for vine length $\mathrm{L}_{3} \times \mathrm{T}_{2}$ (8.67\%),for internodal length in $\mathrm{L}_{2} \times \mathrm{T}_{3}(-20.72 \%)$, for node to first female flower appearance in $\mathrm{L}_{4} \mathrm{~T}_{3}$ $(-15.03 \%)$, for days to first female flower appearance in $L_{3 \times} T_{2}(-23.68 \%)$, for sex ratio in $\mathrm{L}_{1 \times} \mathrm{T}_{1}(13.13 \%)$, for number of seeds per fruits in $\mathrm{L}_{4 \times} \mathrm{T}_{4}(16.97 \%)$, for average fruit weight in $\mathrm{L}_{2} \times \mathrm{T}_{3}(22.48 \%)$, for fruit length in $\mathrm{L}_{3 \times} \mathrm{T}_{1}(23.63 \%)$, for fruit diameter in $\mathrm{L}_{4 \times} \mathrm{T}_{1}$ $(13.56 \%)$, for fruit yield per vine in $\mathrm{L}_{3 \times} \mathrm{T}_{1}(24.74 \%)$. The three best performing $\mathrm{F} 1$ hybrids viz., the cross $\mathrm{L}_{3 \times} \mathrm{T}_{1}(24.74 \%)$ followed by $\mathrm{L}_{4 \times} \mathrm{T}_{1}(19.24 \%)$ exhibited the highest standard heterosis for total yield per vine.
\end{abstract}

\section{Introduction}

Ridge gourd (Luffa acutangula (L) Roxb.) is an important cucurbitaceous vegetable crop of India. Locally it is called as "Turia" (Gujarati) and in Sanskrit "Koshataki". It is grown commercially as a summer and rainy season crop.

It is communally used for vegetable and fibre extraction. The fruits of ridge gourd are delicious and possess good medicinal properties. The edible portion of fruit contains protein, fat, minerals, fibre, carbohydrate, vitamin-A, thiamine, riboflavin, nicotinic acid, vitamin C, oxalic acid (Rahman et al., 2008). Seed of ridge gourd contains 18.3 to $24.3 \%$ oil and 18 to $25 \%$ protein. In different parts of the country, still local strains of ridge gourd are commercially grown by farmers which result into very low yield. Poor performance of local varieties is due to genetic impurities. There are improved varieties of ridge gourd available in our country and are exploited commercially its adoptability in the present climate change in hot known.

Therefore, more emphasis should be paid toward the development of high yield varieties or hybrids. Exploitation of hybrid vigour has been recognized as an important tool for making genetic improvement of yield and its attributing characters in ridge gourd by several earlier workers. Therefore, a study was conducted to evaluate the heterosis of sixteen $F_{1}$ population of ridge gourd. 


\section{Materials and Methods}

The experimental material use for the present investigation comprised of eight genetically diverse parents viz. PKM-1 $\left(\mathrm{L}_{1}\right)$, CO-1 $\left(\mathrm{L}_{2}\right)$, LA $12\left(\mathrm{~L}_{3}\right)$, LA $19\left(\mathrm{~L}_{4}\right)$ used as lines and four testers namely LA $7\left(\mathrm{~T}_{1}\right)$, LA $16\left(\mathrm{~T}_{2}\right)$, LA17 $\left(\mathrm{T}_{3}\right)$ and LA $20\left(\mathrm{~T}_{4}\right)$ and one standard check CO-1.

These parents were crossed by Line $\mathrm{x}$ Tester mating design and sixteen $F_{1}$ hybrids obtained. Sixteen hybrids along with eight parents were raised in randomized block design (RBD) with three replications during 2015 at Department of Horticulture, Agricultural College and Research Institute, Madurai. A inter row spacing of $2 \mathrm{~m}$ and intra row spacing of $2 \mathrm{~m}$ was followed.

All the recommended agronomic package of practices was followed to grow a healthy crop. In each replication, five competitive plants were identified randomly for recording data on days to first true leaf, vine length $\mathrm{cm}$, internodal length $\mathrm{cm}$, days to first female flower appearance, node to first female flower, sex ratio, days to first harvest, average fruit weight $(\mathrm{g})$, fruit length $(\mathrm{cm})$, fruit diameter $(\mathrm{cm})$, number of seeds per fruit and fruit yield per vine $(\mathrm{Kg})$.

The standard procedures were followed for analysis of variance (Gomez and Gomez, 1984) and estimation of heterosis over standard variety CO- 1 as per method of Fonseca and Patterson (1968).

\section{Results and Discussion}

The analysis of variance showed that the mean squares due to hybrids as well as parents were significant for all the characters (Table 1). It indicated the presence of genetic variability among the hybrids as well as parents under study. The variance due to parents against hybrids was found significant for all the traits. Thus, performance of parents and hybrids was completely different from each other for all the traits and existence of overall heterosis was evident from significance of parents verses hybrids.

The primary objective of heterosis breeding is to achieve a quantum jump in yield of crop plants. Heterosis over standard parent for twelve characters is presented in Table 2. The results indicated that the phenomenon of heterosis was of a general occurrence for almost all the characters under study. Several workers reported substantial heterosis for various agronomic characters by Mole et al., (2001) and Gautham et al., (2004).

Negative heterosis is desirable for earliness for days to first female flower appearance, maximum and significant negative heterosis was observed in the cross $\mathrm{L}_{3} \times \mathrm{T}_{2}(-23.68 \%)$ followed the cross $\mathrm{L}_{2} \times \mathrm{T}_{1}(-18.82 \%)$. Negative heterosis with reference to days to female flower appearance was also reported by Rao and Rao (2002) in ridge gourd.

The node to first female flower appearance, maximum and significantly negative heterosis was observed in the cross $\mathrm{L}_{4} \times \mathrm{T}_{3}$ ($15.03 \%)$.Similar findings were also reported by Shaha and Kale (2003). The significant negative heterosis for days to first harvest in the desirable (negative) direction was observed in the cross $\mathrm{L}_{1 \times} \mathrm{T}_{3}(-9.78 \%)$.

Such a significant and negative heterosis was reported by Kantharaj (2003).Heterosis in negative direction is desirable for characters like days to first female flower appearance, node to first female flower appearance, days to first harvest. Earliness (indicated by negative estimates of heterosis) is well recognized and prime objective of any breeding programme as it helps the grower to reap a high market price earlier. 
Table.1 Analysis of variance for various characters in ridge gourd

\begin{tabular}{|c|c|c|c|c|c|c|c|c|}
\hline S. No. & Character & Replications & Geno types & Crosses & Lines & Testers & Line $\mathbf{x}$ Tester & Error \\
\hline & Degree of freedom & 2 & 23 & 15 & 3 & 3 & 9 & 30 \\
\hline 1 & Days to first true leaf & 1.76 & 3.84 & $3.52 *$ & 1.38 & $3.92 *$ & $4.09 *$ & 0.61 \\
\hline 2 & Vine length & 216.57 & $6600.72 *$ & $4157.78 *$ & 3361.05 & 3119.00 & $4769.62 *$ & 1887.13 \\
\hline 3 & Internodal length & 0.25 & $1.88 *$ & $0.80 *$ & $0.77 *$ & $1.03 *$ & $0.74^{*}$ & 0.17 \\
\hline 3 & Days to first female flower & 7.31 & $18.25^{*}$ & $16.53 *$ & $21.95^{*}$ & $30.99 *$ & $9.91 *$ & 3.50 \\
\hline 4 & Node to first female flower & 2.45 & $2.42 *$ & $2.33 *$ & 2.42 & 1.69 & $2.52 *$ & 0.84 \\
\hline 5 & Days to first harvest & 143.27 & $266.88^{*}$ & $264.42 *$ & $540.30 *$ & $135.76 *$ & $215.35^{*}$ & 15.82 \\
\hline 6 & Sex ratio & 0.04 & $2.20 *$ & $2.65 *$ & $2.17 *$ & $3.34 *$ & $2.58 *$ & 0.15 \\
\hline 8 & Average fruit weight & 168.06 & $349.52 *$ & $380.77 *$ & $1034.49 *$ & 154.12 & $238.42 *$ & 89.04 \\
\hline 9 & Fruit length & 23.37 & $34.21 *$ & $39.19 *$ & $57.91^{*}$ & $18.49 *$ & $39.86^{*}$ & 2.51 \\
\hline 10 & Fruit diameter & 0.58 & $5.01 *$ & $2.61 *$ & 1.17 & $4.03 *$ & $2.61 *$ & 0.58 \\
\hline 11 & Number of seeds per fruit & 1.76 & $298.03 *$ & $220.65^{*}$ & $275.58 *$ & 158.77 & $222.97 *$ & 88.92 \\
\hline 12 & Fruit yield per vine & 0.02 & $0.25 *$ & $0.19 *$ & $0.20 *$ & 0.00 & $0.25 *$ & 0.05 \\
\hline
\end{tabular}

* Significant at $5 \%$ level ** Significant at $1 \%$ level

Table.2 Estimates of heterosis (\%) over standard variety (SV) for various characters in ridge gourd

\begin{tabular}{|c|c|c|c|c|c|c|c|c|c|c|c|}
\hline Hybrids & $\begin{array}{l}\text { Vine } \\
\text { length }\end{array}$ & $\begin{array}{l}\text { Inter nodal } \\
\text { length }\end{array}$ & $\begin{array}{l}\text { Days to first } \\
\text { female flower }\end{array}$ & $\begin{array}{l}\text { Node to first } \\
\text { female flower }\end{array}$ & $\begin{array}{c}\text { Days to } \\
\text { first harvest }\end{array}$ & $\begin{array}{l}\text { Sex } \\
\text { ratio }\end{array}$ & $\begin{array}{c}\text { Average } \\
\text { fruit } \\
\text { weight }\end{array}$ & Fruit length & $\begin{array}{c}\text { Fruit } \\
\text { diameter }\end{array}$ & $\begin{array}{l}\text { Number of } \\
\text { seeds per } \\
\text { fruit }\end{array}$ & $\begin{array}{l}\text { Fruit yield/ } \\
\text { vine }\end{array}$ \\
\hline $\mathrm{L}_{1} \times \mathrm{T}_{1}$ & -4.18 & -0.71 & $-18.02 * *$ & -5.97 & $-33.50 * *$ & $13.13 *$ & -4.50 & -3.69 & 11.26 & -1.96 & $-14.92 *$ \\
\hline $\mathrm{L}_{1} \times \mathrm{T}_{2}$ & 1.18 & -1.07 & $-11.32 * *$ & -7.13 & $-25.76 * *$ & $27.76 * *$ & -3.74 & $-10.38 *$ & 5.72 & $10.46 *$ & -1.83 \\
\hline $\mathrm{L}_{1} \times \mathrm{T}_{3}$ & -3.45 & $-12.85 *$ & $-12.44 * *$ & 1.35 & $-9.78 *$ & 11.09 & 5.33 & -3.82 & -4.32 & 9.13 & 4.45 \\
\hline $\mathrm{L}_{1} \times \mathrm{T}_{4}$ & 5.85 & -10.99 & 1.36 & -3.08 & $-11.02 * *$ & 7.35 & 3.23 & $20.01 * *$ & 1.58 & $11.76 *$ & 12.43 \\
\hline $\mathrm{L}_{2} \times \mathrm{T}_{1}$ & 3.93 & $-16.01 *$ & $-18.82 * *$ & 3.66 & -6.35 & 7.48 & $11.77 *$ & 2.44 & 2.06 & 0.65 & $14.27 *$ \\
\hline $\mathrm{L}_{2} \times \mathrm{T}_{2}$ & 2.08 & -8.42 & $-18.18 * *$ & -2.50 & $-25.03 * *$ & 6.94 & $13.81 * *$ & $14.90 * *$ & 10.13 & $13.05 *$ & $16.88 *$ \\
\hline $\mathrm{L}_{2} \times \mathrm{T}_{3}$ & 6.26 & $-20.72 * *$ & $-15.71 * *$ & -0.00 & $-16.79 * *$ & $15.99 * *$ & $22.48 * *$ & $25.97 * *$ & 6.42 & 7.19 & 5.24 \\
\hline $\mathrm{L}_{2} \times \mathrm{T}_{4}$ & 3.04 & -8.38 & $-8.45 *$ & 4.62 & $-10.43 * *$ & 9.46 & 7.59 & 8.14 & 2.10 & 4.58 & 4.58 \\
\hline $\mathrm{L}_{3} \times \mathrm{T}_{1}$ & 6.33 & -11.15 & $-14.19 * *$ & 2.12 & $-31.24 * *$ & -9.25 & 6.59 & $23.63 * *$ & 8.43 & $13.73 * *$ & $24.74 * *$ \\
\hline $\mathrm{L}_{3} \times \mathrm{T}_{2}$ & 8.67 & -12.34 & $-23.68 * *$ & -0.77 & $-34.45 * *$ & $58.91 * *$ & 9.20 & 3.20 & 0.23 & 5.88 & $19.24 * *$ \\
\hline $\mathrm{L}_{3} \times \mathrm{T}_{3}$ & 6.74 & -4.94 & $-17.54 * *$ & 1.35 & $-35.91 * *$ & $14.83 *$ & -1.53 & 8.57 & 4.57 & 5.86 & 3.66 \\
\hline $\mathrm{L}_{3} \times \mathrm{T}_{4}$ & -4.82 & $-16.73 * *$ & $-12.60 * *$ & -3.28 & $-25.76 * *$ & $16.67 * *$ & 5.67 & -6.34 & -8.39 & 1.29 & -2.23 \\
\hline $\mathrm{L}_{4} \times \mathrm{T}_{1}$ & 0.39 & -0.43 & $-14.04 * *$ & 5.59 & -5.18 & 3.06 & 7.18 & 7.20 & 13.56 & $11.76 *$ & 2.49 \\
\hline $\mathrm{L}_{4} \times \mathrm{T}_{2}$ & 3.37 & -5.69 & $-18.02 * *$ & -2.89 & $-20.07 * *$ & $19.59 * *$ & 2.17 & $-13.07 * *$ & -4.05 & $16.78 * *$ & -0.26 \\
\hline $\mathrm{L}_{4} \times \mathrm{T}_{3}$ & 7.38 & $-12.89 *$ & $-10.77 *$ & $-15.03 * *$ & $-25.62 * *$ & $35.85 * *$ & $14.13 * *$ & -1.09 & 12.50 & 6.54 & $17.02 *$ \\
\hline $\mathbf{L}_{4} \times \mathbf{T}_{4}$ & -3.70 & $-16.49 *$ & $-15.87 * *$ & -2.50 & $-25.40 * *$ & $62.45 * *$ & $13.79 * *$ & -8.34 & 2.17 & $16.97 * *$ & 12.30 \\
\hline
\end{tabular}


Yield is the foremost character for any breeding programme. It is a complex trait resulting from the interaction of its component characters of a crop. In ridge gourd, number of fruits per plant, fruit weight and fruit size are the direct component of yield. Average fruit weight can contribute for yield, the cross $\mathrm{L}_{2} \times \mathrm{T}_{3}$ exhibited maximum heterosis of 22.48 per cent over standard better variety, which is confirmed with Shaha and Kale (2003a) in ridge gourd. The fruit yield per vine exhibited positive and significant heterosis over better parent the cross $\mathrm{L}_{3} \times \mathrm{T}_{1}(24.74 \%)$ followed by $\mathrm{L}_{3} \times \mathrm{T}_{2}$ $(19.24 \%)$ which confirms with earlier findings by Mole et al., (2001).Hayes and Jones (1916) reported the first generation crosses in cucumber frequently exhibited high parent heterosis increased fruit size and number of fruits per plant. Therefore yield can more accurately be estimated by the number of fruits per plant and it would be possible to achieve in this crop by manipulating this particular trait. Hence breeder concentrate mainly towards number of fruits rather than the fruit size to increase the yield.

The $\mathrm{L}_{4} \times \mathrm{T}_{4}$ cross exhibited maximum and significant heterosis 16.97 for per cent number of seeds per fruit. Mole et al., (2001) reported similar positive heterosis for number of seeds per fruit in ridge gourd. The fruit length in the cross $\mathrm{L}_{2} \times \mathrm{T}_{3} 25.97$ per cent showed maximum and positive significant heterosis and is confirmed with Hedau and Sirohi (2004). The fruit diameter in, $\mathrm{L}_{4} \times \mathrm{T}_{1}$ showed maximum heterosis of 13.56 per cent over commercial check. These findings are in consonance with Hedau and Sirohi (2004).

Cross combination $\mathrm{L}_{3} \times \mathrm{T}_{1}$ produced the highest significant standard heterosis (13.73 per cent) for fruit yield per vine and also positive economic heterosis for yield components traits viz fruit length and number of seeds per fruit. Similarly, in the remaining crosses showing economic heterosis for fruit yield also exhibited heterosis for at least one or more yield contributing characters. This supports the long held view that total yield could be the result of "combinational heterosis" (Harberg, 1952) i.e., expression of heterosis due to favorable combination of yield components in a hybrid. Patel and Desai (2008), Sharma, et al., (2012) and Mule et al., (2012) reported that those crosses which are superior in yield also exhibited heterosis in one or more yield contributing component traits. On the basis of above results, these cross combinations could be recommended for commercial exploitation of heterosis. The hybrids $\mathrm{L}_{3} \times \mathrm{T}_{1}$ and $\mathrm{L}_{1} \times \mathrm{T}_{4}$ could be commercially exploited after assessing their stability.

\section{References}

Fonseca, S. and Patterson, F.L. 1968. Hybrid vigour in seven parental diallel crosses in common winter wheat (Triticum aestivum L.). Crop Sci., 8: 85-88.

Gautham, B., Neeraja, G. and Reddy, I.P. 2004. Evaluation of promising hybrids in ridge gourd (Luffa acutangula L.). J. Res. ANGRAU. 32: 34-38.

Gomez, K.A. and Gomez, A.A. 1984. Statistical procedure for agricultural research. John Wiley and sons, Inc. London, UK (2nd edtn) 13-175.

Harberg, A. 1952. Heterosis in F1 combination in Galeopsis I and II. Hereditas, Land, 1: 221-225 Fide: Indian J. Genet., 29: 53-61.

Hayes, H.K. and Jones, D.F. (1916).First generation crosses in cucumber. Ann.Rep. Conn. Agric. Expt.Stn., 31922

Hedau, N. K. and Sirohi, P. S., 2004, Heterosis studies in ridge gourd. Indian J. Hort., 61(3): 236-239. 
Kantharaj, N. M., 2003, Studies on heterosis and combining ability in ridge gourd (Luffa acutangula (Roxb.) L.). M. Sc. (Hort.) Thesis, Univ. Agric. Sci., Dharwad (India).

Mole, T.J., Dev, S.N., Rajan, S. and Sadhankumar, P.G. 2001. Heterosis and combining ability in ridge gourd (Luffa acutangula ROXB.). Veg. Sci., 28: 165167.

Mule, P.N., Khandelwal, V., Lodam, V.A., Shinde, D.A., Patil, P.P. and Patil, A.B. 2012. Heterosis and combining ability in cucumber (Cucumis sativus L.). Madras Agric. J., 99: 420-423.

Patel, S.R. and Desai, D.T. 2008. Heterosis and combining ability studies in sponge gourd [Luffa cylindrica (Roem) L.]. Veg. Sci., 35: 199-200.
Rahman, A.H., Anisuzzaman, M., Ferdous A., A.K., Rafiul, I. and Naderuzzaman, A.T. 2008. Study of nutritive value and medicinal uses of cultivated cucurbits. J. Appl. Sci. Res., 4: 555-558.

Rao, B. N. and Rao, P. V., 2002, Heterosis in ridge gourd (Luffa acutangula (Roxb.) L.). J. Res. ANGRAU., 30 (1): 11-18.

Shaha, S. R. and Kale, P. N., 2003, Diallel analysis for combining ability in ridge gourd. J. Maharastra Agril. Univ., 28(3): 252-254.

Sharma, D.R., Choudhary, M.R., Jakhar, M.L. and Dadheech, S. 2012. Heterosis in bottle gourd (Lagenaria siceraria (Mol.) Standl.). Int. J. Life Sci., 1: 212216.

\section{How to cite this article:}

Nandhini, D., M. Ananthan, V. Krishnamoorthy and Anand, G. 2018. Studies on Heterosis in Ridge Gourd (Luffa accutangula (L) Roxb). Int.J.Curr.Microbiol.App.Sci. 7(05): 3126-3130. doi: https://doi.org/10.20546/ijcmas.2018.705.365 